\title{
Stripping Voltammetric Determination of Copper (II) on an Overoxidized Polypyrrole Functionalized with Nitroso-R
}

\author{
Alireza Mohadesi, ${ }^{*}, a$ Ashraf Salmanipour, ${ }^{a}$ Sayed Ziae Mohammadi, ${ }^{a}$ Ali Pourhatami ${ }^{b}$ \\ and Mohammad Ali Taher ${ }^{c}$ \\ a Department of Chemistry, Payame Noor University, PO Box 76175-559, Kerman, Iran \\ ${ }^{b}$ Department of Chemistry, Azad University of Yazd, Yazad, Iran \\ c Department of Chemistry, Shahid Bahonar University, PO Box 76175-133, Kerman, Iran
}

\begin{abstract}
No presente trabalho é apresentado um método para a determinação de $\mathrm{Cu}$ em amostras de cabelo humano e água por voltametria de redissolução anódica de pulso diferencial. Foi provado que a eletropolimerização do pirrol ocorre em presença do ânion dopante Nitroso-R. O polipirrol dopado com Nitroso-R foi deposido sobre a superfície da platina, e reage com $\mathrm{Cu}$ (II) em pHs neutros, originando um complexo. Essa complexação entre o Nitroso- $\mathrm{R}$ e o $\mathrm{Cu}(\mathrm{II})$ produz o acúmulo de $\mathrm{Cu}(\mathrm{II})$ na superfície a partir de a circuito aberto. $\mathrm{O}$ eletrodo resultante com $\mathrm{Cu}$ (II) complexado foi então transferido para um tampão de acetato, e submetido a voltametria de redissolução anódica, promovendo o aparecimento de um pico de corrente a $+0,08 \mathrm{~V}$. Depois da avaliação do comportamento funcional analítico foi construído um gráfico de calibração a partir de 1,2 a $243,9 \mathrm{ng} \mathrm{mL}^{-1}$ e o limite de detecção foi de $0,7 \mathrm{ng} \mathrm{mL}^{-1}$. O método foi utilizado para a determinação de íons cobre em amostras de água e cabelo humano. Os resultados indicam a capacidade do método para a determinação deste íon em amostras reais. Além disso, a rápida e conveniente regeneração do eletrodo permite sua utilização em várias análises.
\end{abstract}

In the present paper a method for the determination of $\mathrm{Cu}$ in human hair and water samples by differential pulse anodic stripping voltammetry is presented. It has been proven that pyrrole electropolymerizes in present of Nitroso-R as dopant anion. Nitroso-R doped in polypyrrole film coated on platinum surface then reacts with $\mathrm{Cu}(\mathrm{II})$ in neutral $\mathrm{pHs}$ giving rise to a complex. This complexation between Nitroso- $\mathrm{R}$ and $\mathrm{Cu}$ (II) achieves the accumulation of $\mathrm{Cu}$ (II) from the sample solutions to the electrode surface at open circuit condition. The resulting electrode with complexed $\mathrm{Cu}$ (II) can then transfer to an acetate buffer and subject to anodic stripping voltammetry which promotes the appearance of a peak at $+0.08 \mathrm{~V}$. After the evaluation of the analytical performance a calibration graph was constructed from 1.2 to $243.9 \mathrm{ng} \mathrm{mL}^{-1}$ and the detection limit was $0.7 \mathrm{ng} \mathrm{mL}^{-1}$. The method was used for determination of copper ions in water and human hair samples. The results indicate the ability of method for the determination of this ion in real samples. Also, the rapid and convenient regeneration of electrode allows the use of a single modified electrode in multiple analyses.

Keywords: polypyrrole, Nitroso-R,copper, stripping analysis

\section{Introduction}

Copper is a metal of prime environmental concern. ${ }^{1}$ Voltammetric techniques are known to show unique advantages both economical, i.e. low initial and running costs, and strictly analytical like the ability to determine low levels of metal in different matrixes ranging from seawater to melted snow. In particular, stripping techniques are perfectly suited

*e-mail: mohadesi_a@yahoo.com for trace and ultratrace metal determination. ${ }^{2}$ The application of voltammetric techniques in the determination of trace copper has been reviewed. ${ }^{3}$ Of these methods, anodic stripping voltammetry on a hanging mercury drop electrode (HMDE) has gained wide acceptance for copper determination. The disadvantages of this method are the formation inter-metallic compounds with co-existing metal ions at the electrode, which can cause serious error, toxicity of mercury used as electrode and the presence of ligand such as chloride in the sample solution, which disturbs the stripping polarographic wave. ${ }^{1-3}$ 
Recently, because of these advantageous, there has been a growing interest in the use of chemically modified electrodes (CME) for trace metal stripping analysis. With this process, accumulation usually occurs by reactions between an analyte and an immobilized modifier at the solid state electrode surface. ${ }^{3,4}$

Electrically conducting polymers (ECPs), such as polyaniline or polypyrrole (PPy), can be used for the immobilization of complexing reagents for trace metal complexation/accumulation with voltammetric detection of the complexed metal ion..$^{5,6}$ The application of anionic ligands as functional dopant incorporated into a PPy matrix for the stripping analysis of metal ions has been reviewed. ${ }^{7}$ The preparation of these functional PPy films is very simple, controllable and reproducible by electrochemical oxidizing pyrrole monomers in the presence of the target anionic reagents. However, a major limitation lies in the high background currents typically encountered with modified PPy films. These currents mask the relatively smaller metal-chelate binding, thereby making metal detection difficult. One solution of this problem is to overoxidize PPy to decrease these background currents. ${ }^{8-11}$

The aim of this work was to develop a simple, selective and sensitive system for determination of $\mathrm{Cu}$ (II) by stripping voltammetry on platinum electrode modified with overoxidized PPy (OPPy) doped with Nitroso-R. The results obtained led to the development of a voltammetric method for the determination of copper with a wide linear range and low detection limit. The resulting modified electrode does not use mercury and therefore, has a positive environmental benefit. The method, which is reasonably sensitive and selective, has been successfully applied to the determination of trace amount of copper in water and human hair samples.

\section{Experimental}

\section{Reagents}

Pyrrole (Fluka) was distilled under reduced pressure before use. Nitroso-R (Merck) was used as received. Metal ion solutions in selectivity section were prepared from their nitrate salts and were purchased from Merck and were of analytical grade. All aqueous solutions were prepared with double-distillated water.

\section{Apparatus}

Voltammetric experiments were performed using Metrohm electroanalyzer Model 797 VA computrace. The measurements recorded using VA computrace version
1.2 (Metrohm) running under windows XP. Working electrodes were $3 \mathrm{~mm}$ diameter platinum disks constructed in-house. The counter electrode was a platinum wire and the reference electrode was $\mathrm{Ag} / \mathrm{AgCl}$, both from Metrohm. A Metrohm pH meter, Model 710, was used for $\mathrm{pH}$ measurements.

\section{Film preparation}

PPy/Nitroso-R films were prepared potentiostatically by holding the potential at $+0.75 \mathrm{~V}$ for $50 \mathrm{~s}$. The growth solution was an aqueous pyrrole and Nitroso-R mixture, at $0.2 \mathrm{~mol} \mathrm{~L}^{-1}$ pyrrole and $10 \mathrm{mmol} \mathrm{L}^{-1}$ Nitroso-R. The overoxidation of the PPy/Nitroso-R films was carried out in $0.1 \mathrm{~mol} \mathrm{~L}^{-1} \mathrm{NaOH}$ by cycling the potential between 0 and $1.2 \mathrm{~V}$ at $50 \mathrm{mV} \mathrm{s}^{-1}$ for two cycles.

\section{Stripping voltammetric determination of copper (II)}

For accumulation, an OPPy/Nitroso-R modified electrode was immersed in a $0.2 \mathrm{~mol} \mathrm{~L}^{-1}$ ammonia buffer (pH 7) containing $\mathrm{Cu}(\mathrm{II})$, and stirred for $8 \mathrm{~min}$; the electrode was then washed with water and transferred into a deaerated $0.1 \mathrm{~mol} \mathrm{~L}^{-1}$ acetate buffer ( $\mathrm{pH} 3.5$ ). After accumulation on the electrode surface, preconcentrated copper ions were reduced at $-0.5 \mathrm{~V}$ for $10 \mathrm{~s}$. The potential was then scanned in the positive direction by cyclic voltammetry (scan rate, $50 \mathrm{mV} \mathrm{s}^{-1}$ ) between -0.5 and $+0.4 \mathrm{~V}$ or differential pulse voltammetry (pulse amplitude, $50 \mathrm{mV}$; pulse interval $1 \mathrm{~s}$; and scan rate, $50 \mathrm{mV} \mathrm{s}^{-1}$ ) between -0.3 and $+0.3 \mathrm{~V}$.

\section{Pretreatment of real samples}

The procedure of wet ashing of human hair has been described by Mohadesi et al. ${ }^{12}$ The hair sample was rinsed with acetone, and $4.20 \mathrm{~g}$ of dried sample was accurately weighted and burned in a furnace at $700{ }^{\circ} \mathrm{C}$ until a white powder was obtained. The obtained ash was dissolved in a minimum volume of concentrated nitric acid with heating. The solution was boiled to expel brown fumes, cooled and diluted with distilled water to $20 \mathrm{~mL}$ in a calibration flask. Then, $0.3 \mathrm{~mL}$ of this solution was added to $20 \mathrm{~mL}$ of ammonia buffer at $\mathrm{pH}$ 7 , and the general procedure was used on the resultant solution. For the analysis of river and tap water, samples were exchanged with distillated water used for the preparation of ammonia buffer ( $\mathrm{pH} 7$ ), and the general procedure was used on these resultant solutions. In all real samples, the standard addition method was applied for the determinations of copper. 


\section{Results and Discussion}

Voltammetric behavior of copper(II) in OPPy/Nitroso-R films

Since the Nitroso-R (Figure 1) was the only anion present in the electropolymerized solution, it was incorporated with the growing cationic PPy film to maintain electroneutrality in the polymer matrix.

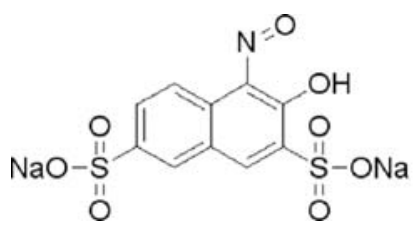

Figure 1. Nitroso-R as an anion/chelator.

This PPy/Nitroso-R film was examined for metal-ion complexing ability by medium-exchange voltammetry. As was shown in Figure 2, results from experiments on PPy films for trace $\mathrm{Cu}(\mathrm{II})$ deposition and stripping did not indicate noticeable current change after accumulation in a solution containing copper metal ions. This is probably due to the inaccessibility of the complexing agent (Nitroso-R) to the copper metal ions. Also, the large background currents resulting from the conducting and electroactive PPy that is likely to mask the relatively smaller current that may result from the copper-chelate complex..$^{8-12}$ For these small currents to appear obtained by stripping preconcentrated metal ions, large background currents may decrease. This decrease can be obtained by the overoxidation of PPy films. Figure 3 shows the overoxidation process of PPy/Nitroso-R film using two cycles in a $0.1 \mathrm{~mol} \mathrm{~L}^{-1} \mathrm{NaOH}$ solution. In the first scan, two anodic peaks are observed over the whole potential range. These two peaks are ascribed to the overoxidation of PPy film. ${ }^{13}$ As can be seen in Figure 3, no cathodic peak can be observed on the reverse scan, which indicates that the overoxidation process is electrochemically irreversible. A strong decrease in the current in duration second cycle was shown to decrease conductivity of PPy film because of an irreversible electrochemical transformation of the polymer film during the first cycle. This overoxidation is caused by a nucleophilic attack on the pyrrole units by a solvent or $\mathrm{OH}^{-}$, which results in a loss of the conjugated structure of the polymer. ${ }^{13,14}$

CVs of PPy/Nitroso-R film were recorded and compared in acetate buffer ( $\mathrm{pH}$ 3.5) before and after the overoxidation process. Results indicate that overoxidation of the PPy film decreased the background current. Although not electrochemically active, the polymer can still allow the complexation of copper, if the Nitroso-R still exists in the OPPy film.

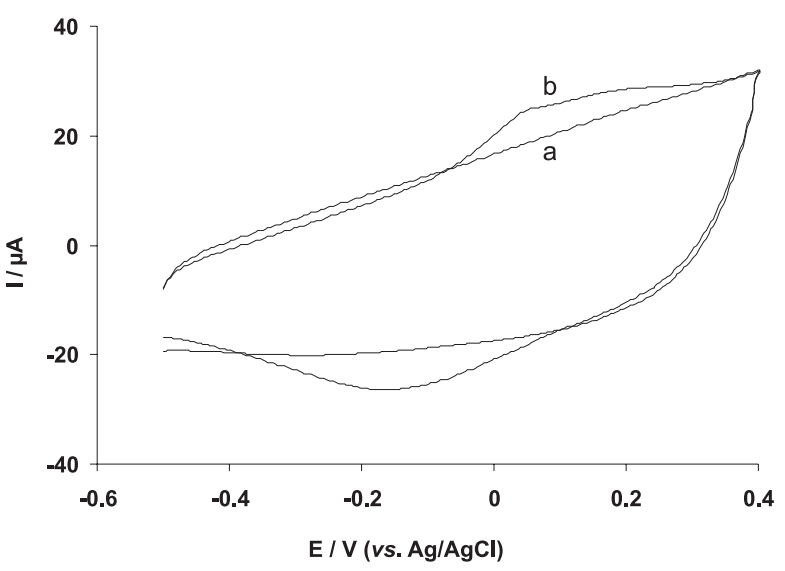

Figure 2. Cyclic voltammograms in acetate buffer at $\mathrm{pH} 3.5$ after opencircuit accumulation in ammonia buffer $\mathrm{pH}$ 7. (a) PPy/Nitroso-R electrode, no $\mathrm{Cu}$ (II) in accumulation medium, (b) PPy/Nitroso-R electrode, with $0.5 \mathrm{mg} \mathrm{L}^{-1} \mathrm{Cu}(\mathrm{II})$ in accumulation medium. The accumulation time was $10 \mathrm{~min}$ and the scan rate was $50 \mathrm{mV} \mathrm{s}^{-1}$.

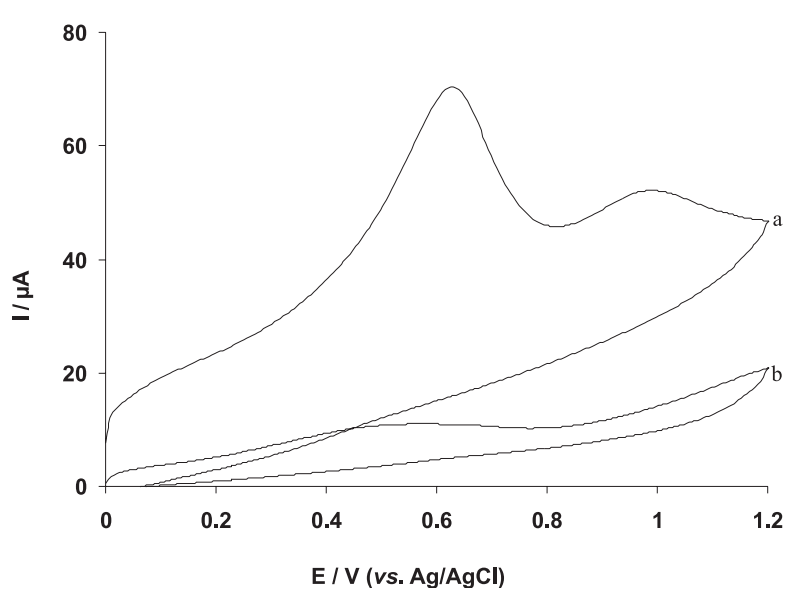

Figure 3. Cyclic voltammograms (scan rate $50 \mathrm{mV} \mathrm{s}^{-1}$ ) for the overoxidation of PPy/Nitroso-R in $0.1 \mathrm{~mol} \mathrm{~L}^{-1} \mathrm{NaOH}$. (a) first cycle and (b) second cycle.

Figure $4 \mathrm{~b}$ shows typical cyclic voltammograms for the detection of $\mathrm{Cu}(\mathrm{II})$ following open-circuit accumulation onto OPPy/Nitroso-R film. An anodic peak at $+0.95 \mathrm{~V}$ and a cathodic peak at $-0.16 \mathrm{~V}$ can be observed, which are related to the oxidation and reduction of accumulated copper, respectively. To prove further the importance of Nitroso-R as a chelator reagent in the PPy matrix, overoxidized PPy films doped with $\mathrm{NO}_{3}{ }^{-}$and $\mathrm{SO}_{4}{ }^{2-}$ were prepared, and used for the accumulation and stripping of $\mathrm{Cu}(\mathrm{II})$. The results were showed no significant peaks in the case of $\mathrm{OPPy} / \mathrm{Br}$ and $\mathrm{OPPy} / \mathrm{SO}_{4}$. These results show the importance of doping Nitroso-R in PPy film for the preconcentration of $\mathrm{Cu}(\mathrm{II})$.

From the above observations, under the conditions of the experiments, the possible pathways for the analysis cycle are postulated below ("aq" or "surf" subscript means compound is in aqueous solution or electrode surface): 


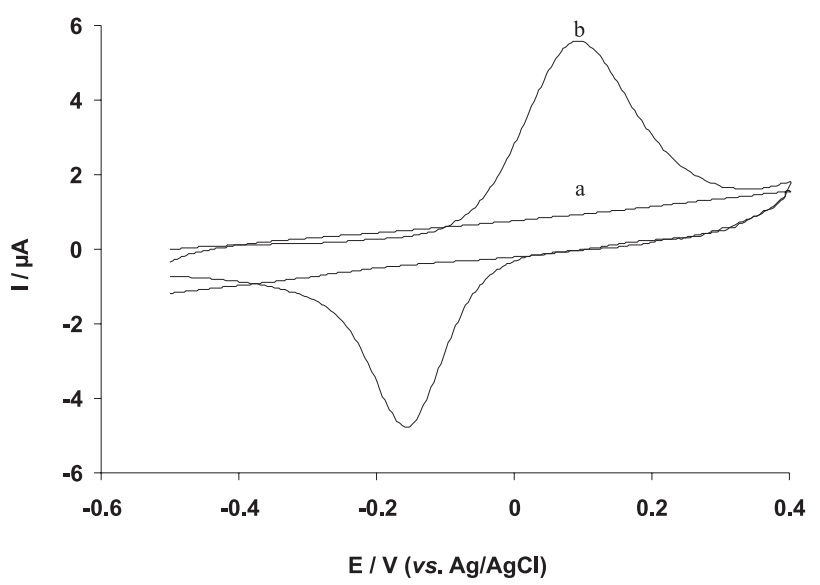

Figure 4. Cyclic voltammograms in acetate buffer at $\mathrm{pH} 3.5$ after opencircuit accumulation in ammonia buffer $\mathrm{pH}$ 7. (a) OPPy/Nitroso-R electrode, no $\mathrm{Cu}$ (II) in accumulation medium, (b) OPPy/Nitroso-R electrode, with $0.5 \mathrm{mg} \mathrm{L}^{-1} \mathrm{Cu}(\mathrm{II})$ in accumulation medium. The accumulation time was $10 \mathrm{~min}$ and the scan rate was $50 \mathrm{mV} \mathrm{s}^{-1}$.

PPy Film preparation from solution containing nitroso-R and pyrrole: ${ }^{7,8}$

n Pyrrole $_{(\mathrm{aq})}+$ Nitroso $-\mathrm{R}_{(\mathrm{aq})} \stackrel{\text { in }+0.75 \mathrm{~V}}{\longrightarrow}$ PPy/Nitroso - $\mathrm{R}_{\text {(surf) }}$

Overoxidation of PPy film in $\mathrm{NaOH}$ solution: ${ }^{8}$

PPy/Nitroso - $\mathrm{R}_{\text {(surf) }} \stackrel{\text { Scan between } 0 \text { and } 1.2 \mathrm{~V}}{\longrightarrow}$ OPPy/Nitroso - $\mathrm{R}_{\text {(surf) }}$

Accumulation of $\mathrm{Cu}(\mathrm{II})$ from sample solutions containing $\mathrm{Cu}(\mathrm{II}):^{15}$

$\mathrm{Cu}(\mathrm{II})_{\text {(aq) }}+$ Nitroso $-\mathrm{R}_{\text {(surf) }} \stackrel{\text { open circuit }}{\longrightarrow}[\mathrm{Cu}(\mathrm{II})-\text { Nitroso }-\mathrm{R}]_{\text {(surf) }}$

Reduction of accumulated $\mathrm{Cu}(\mathrm{II})$ in clean acetate buffer: ${ }^{16,17}$

$[\mathrm{Cu}(\mathrm{II})-\text { Nitroso }-\mathrm{R}]_{\text {(surf) }}+2 \mathrm{e} \stackrel{\text { in }-0.5 \mathrm{~V}}{\longrightarrow} \mathrm{Cu}_{\text {(surf }}^{0}+$ Nitroso $-\mathrm{R}_{\text {(surf) }}$

Stripping of reduced copper in clean acetate buffer: ${ }^{16,17}$

$\left[\mathrm{Cu}^{0}\right]_{\text {(surf) }} \stackrel{\text { Scan from }-0.3 \text { to }+0.3 \mathrm{~V}}{\longrightarrow}[\mathrm{Cu}(\mathrm{II})]_{(\text {surf) }}+2 e$

pH of the accumulation and stripping medium

The chelating properties of Nitroso-R with metal cations have been demonstrated to be $\mathrm{pH}$ dependent. ${ }^{15,18,19}$ Therefore, the effect of the $\mathrm{pH}$ on the stripping peak current was studied in the range of 4.5-9.5. The stripping peak currents were found to increase as the $\mathrm{pH}$ of the accumulation solution (ammonia buffer) was increased. The maximum stripping currents are to be expected at $\mathrm{pHs}$ between 6-7.5. A similar behavior for the best $\mathrm{pH}$ for complexion between Nitroso-R and copper(II) previously reported using other methods..$^{15} \mathrm{pH} 7$ was applied as the $\mathrm{pH}$ of the accumulation medium for copper determination. Also, the effect of the stripping medium on both the voltammogram shape and the stripping current was studied. The best choice for the ability to give the best shape and the highest current was an acetate buffer with pH 3.5.

\section{Reduction potential and reduction time}

The best reduction potential for copper determination was studied. No significant changes in the anodic stripping peak current were observed for more negative reduction potentials of copper than $-0.3 \mathrm{~V}$. Also, potentials more negative than $-0.6 \mathrm{~V}$ led to decreased peak currents. This is mainly due to co-hydrogen evolution at such high potentials. Hence, $-0.5 \mathrm{~V}$ was employed as an optimum reduction potential for copper(II) determination.

Also the effect of the reduction time on the anodic peak current of copper was estimated. The anodic stripping peak currents were found to increase linearly, increasing the reduction time by up to $9 \mathrm{~s}$. After this time, the peak currents remained constant. Therefore, reduction times of $10 \mathrm{~s}$ were used for all subsequent measurements.

\section{Preconcentration time}

The dependence of the anodic stripping peak current on the preconcentration time for two different copper(II) concentrations ( 5 and $225 \mathrm{ng} \mathrm{mL}^{-1}$ ) was studied. The peak current was found to increase with increasing preconcentration time, indicating an enhancement of the $\mathrm{Cu}$ (II) uptake at the electrode surface. Normally, the increase in the response current continues until the maximum signal level (presumably corresponding to an equilibrium time) is attained. The thusobtained results indicated that the attainment of a steady state accumulation level of $\mathrm{Cu}(\mathrm{II})$ at the electrode surface requires an exposure time of $5 \mathrm{~min}$ for $225 \mathrm{ng} \mathrm{mL}^{-1}$ and $8 \mathrm{~min}$ for $5 \mathrm{ng} \mathrm{mL}^{-1} \mathrm{Cu}(\mathrm{II})$. Hence, a $8 \mathrm{~min}$ preconcentration time was employed in all subsequent experiments.

\section{Calibration curve, detection limit and reproducibility}

After optimization of all the variables of differential pulse (DP) voltammetry for the determination of $\mathrm{Cu}$ (II), the variation in the peak current with the $\mathrm{Cu}$ (II) concentration was studied. Some of the resulting DP voltammograms obtained at various $\mathrm{Cu}$ (II) concentrations and the corresponding current-concentration plot are shown in Figure 5. A linear calibration graph was obtained in the concentration range of 1.2-243.9 $\mathrm{ng} \mathrm{mL}^{-1} \mathrm{Cu}(\mathrm{II})$. 


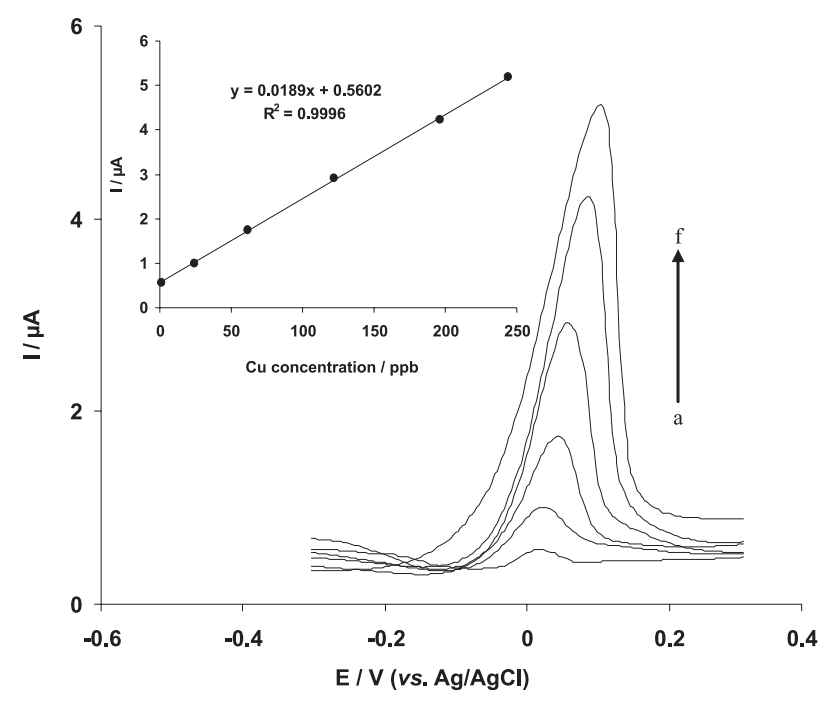

Figure 5. Differential pulse anodic stripping voltammograms of copper(II) accumulated OPPy/Nitroso-R modified electrode, concentrations of (a-f) 1.2, 24.3, 61.7, 121.9, 196.1 and $243.9 \mathrm{ng} \mathrm{mL}^{-1} \mathrm{Cu}(\mathrm{II})$. Inset: Related calibration graph. Other conditions: Accumulation medium $=$ ammonia buffer $\mathrm{pH} 7$, Accumulation time $=8 \mathrm{~min}$, Reduction potential $=-0.5 \mathrm{~V}$, Reduction time $=10 \mathrm{~s}$, scan rate $=50 \mathrm{mV} \mathrm{s}^{-1}$, pulse amplitude $=50 \mathrm{mV}$, pulse interval $=1 \mathrm{~s}$ and stripping medium $=$ acetate buffer $\mathrm{pH} 3.5$.

The limit of detection was calculated by making replicate current measurements at $0.08 \mathrm{~V}$ for a blank solution. The detection limit based on three-times of their standard deviation per slope of the calibration curve gave a value of $0.7 \mathrm{ng} \mathrm{mL}^{-1} \mathrm{Cu}$ (II).

For five successive detections of 5 and $200 \mathrm{ng} \mathrm{mL}^{-1}$ $\mathrm{Cu}(\mathrm{II})$, the relative standard deviations were 1.8 and $1.1 \%$, respectively.

\section{Effect of interferences}

The ability of Nitroso-R to complex with metal ions has been reported based on various studies. The stability of these complexes is $\mathrm{pH}$ dependent. ${ }^{15,18,19}$ The presence of other metal ions could interfere with $\mathrm{Cu}$ (II) determination if they compete for complexation at the Nitroso-R complexing sites in OPPy film. When the developed procedure was exployed for the determination of $50 \mu \mathrm{g} \mathrm{L} \mathrm{L}^{-1} \mathrm{Cu}$ (II) with optimum conditions, no interference was encountered for additions of $500 \mu \mathrm{g}$ $\mathrm{L}^{-1}$ each of $\mathrm{Mg}(\mathrm{II}), \mathrm{Ca}(\mathrm{II}), \mathrm{Pb}(\mathrm{II}), \mathrm{Mn}(\mathrm{II}), \mathrm{Zn}(\mathrm{II}), \mathrm{Cd}(\mathrm{II})$, $\mathrm{Na}(\mathrm{I}), \mathrm{Au}(\mathrm{III}), \mathrm{K}(\mathrm{I})$. However the presence of $500 \mu \mathrm{g} \mathrm{\textrm {L } ^ { - 1 }}$
$\mathrm{Co}(\mathrm{II}), \mathrm{Hg}(\mathrm{II}), \mathrm{Ag}$ (I), Ni(II) and Fe(III) caused 10, 13, 17, 9 and $21 \%$ depressions of the $\mathrm{Cu}$ (II) peak, respectively. These depressions are due to the ability of Nitroso-R for complexation with these metal ions.

\section{Real samples}

The concentration of $\mathrm{Cu}$ (II) in sample solutions (human hair, river water and tap water) was determined by the experimental method mentioned above. As presented in Table 1 , the concentration of $\mathrm{Cu}$ in human hair sample obtained in the present procedure $\left(11.16 \mu \mathrm{g} \mathrm{g}^{-1}\right)$ is in the same range as the levels of Mohadesi et al. ${ }^{12}\left(12.41 \mu \mathrm{g} \mathrm{g}^{-1}\right)$, Ramakrishna et al. ${ }^{20}\left(13.90 \mu \mathrm{g} \mathrm{g}^{-1}\right)$, Bertazzo et al. ${ }^{21}\left(14.89-15.29 \mu \mathrm{g} \mathrm{g}^{-1}\right)$ and Sreenivasa Rao et al. ${ }^{22}$ (4.90-22.54 $\left.\mu \mathrm{g} \mathrm{g}^{-1}\right)$ reported. Also, the results show the presence of $\mathrm{Cu}$ (II) in natural water samples. These amounts are around of the median concentration of copper in natural water samples (4-10 $\mathrm{ng} \mathrm{mL}^{-1}$ ) reported by Environmental Protection Agency. ${ }^{23}$ The reliability of the method was also checked by spiking the samples, and the accuracy of the method was examined by recovery experiments. Samples were analyzed using an independent technique (flame atomic absorption spectroscopy, FAAS). As presented, the results and recoveries were good.

\section{Regeneration of electrode}

The ability of copper ions to form stable complexes with EDTA forms the basis of the regeneration step. Due to the high concentration of EDTA $\left(0.2 \mathrm{~mol} \mathrm{~L}^{-1}\right)$ employed, the copper ions bound to the electrode surface dissolved in solution as EDTA-Cu(II) chelates, which are presumably more stable than Nitroso- $\mathrm{R}-\mathrm{Cu}$ (II) chelates. The idea here is to reuse the same OPPy/Nitroso-R electrode for several experiments.

The results gave in Figure 6 shows that an used electrode can be completely regenerated after at least $2 \mathrm{~min}$ in EDTA solution. There is no significant difference in the response of a regenerated electrode compared to a new one (compare voltammograms b and d in Figure 6). Regeneration of electrode in EDTA solution can be showed by below reaction: ${ }^{24}$

$$
\begin{gathered}
{[\mathrm{Cu}(\mathrm{II})-\text { Nitroso }-\mathrm{R}]_{(\text {surf) }}+\text { EDTA }_{\text {(aq) }} \stackrel{\text { Open circuit }}{\longrightarrow}} \\
{[\mathrm{Cu}(\mathrm{II})-\mathrm{EDTA}]_{\text {(aq) }}+\text { Nitroso }-\mathrm{R}_{\text {(surf) }}}
\end{gathered}
$$

\begin{tabular}{|c|c|c|c|c|c|c|}
\hline Sample & $\begin{array}{l}\text { Present method/ } \\
\quad\left(n g \mathrm{~mL}^{-1}\right)^{\mathrm{a}}\end{array}$ & $\begin{array}{l}\text { AAS method/ } \\
\left(\mathrm{ng} \mathrm{mL}^{-1}\right)^{\mathrm{a}}\end{array}$ & Recovery/(\%) & $\begin{array}{l}\text { Spiked } \mathrm{Cu}(\mathrm{II}) / \\
\left(\mathrm{ng} \mathrm{mL}^{-1}\right)\end{array}$ & $\begin{array}{c}\text { Found } \mathrm{Cu}(\mathrm{II}) / \\
\left(\mathrm{ng} \mathrm{mL}^{-1}\right)^{\mathrm{a}}\end{array}$ & Recovery/(\%) \\
\hline River water & $6.63 \pm 0.18$ & $6.84 \pm 0.08^{b}$ & 96.92 & 100 & $106.52 \pm 2.35$ & 99.89 \\
\hline Tap water & $3.19 \pm 0.05$ & $3.22 \pm 0.10^{\mathrm{b}}$ & 99.06 & 100 & $100.03 \pm 1.94$ & 99.75 \\
\hline Human hair $^{\mathrm{c}}$ & $13.02 \pm 0.48$ & $12.89 \pm 0.05$ & 101.00 & - & - & - \\
\hline
\end{tabular}

Table 1. Determination of $\mathrm{Cu}(\mathrm{II})$ in natural water and human hair samples

${ }^{\mathrm{a}}$ Mean of three determinations \pm standard deviation. ${ }^{\mathrm{b}}$ After vacuum evaporator concentration. ${ }^{\mathrm{c}}$ Results are given in $\mu \mathrm{g} \mathrm{g}^{-1}$. 
Table 2. Comparison of some properties of the present work with other studies ${ }^{\mathrm{a}}$

\begin{tabular}{|c|c|c|c|c|c|c|c|c|}
\hline No. & Modifier & Matrix & $\mathrm{t}_{\mathrm{a}} /(\min )$ & $\mathrm{LOD} /\left(\mu \mathrm{g} \mathrm{L}^{-1}\right)$ & $\mathrm{LR} /\left(\mu \mathrm{g} \mathrm{L}^{-1}\right)$ & $\mathrm{RSD} / \%$ & Real samples & Ref. \\
\hline 1 & $\begin{array}{l}\text { 3-(2-Pyridyl)-5,6-diphenyl-4,40- } \\
\text { disulfonate-1,2,4-triazine }\end{array}$ & PPy & 5 & 63 & $63-630$ & - & - & 6 \\
\hline \multirow[t]{2}{*}{2} & Pyrocatechol Violet & PPy & 10 & 6.3 & - & 8 & - & 25 \\
\hline & $\begin{array}{l}\text { 4,5-Dihydroxy-3-(p- } \\
\text { sulfophenylazo)-2,7-naphthalene } \\
\text { disulfonic Acid }\end{array}$ & OPPy & 15 & 1.1 & $2-250$ & 3.1 & Natural water, Human hair & 31 \\
\hline 3 & 2,3-dimercaptosuccinic acid & SAM & 15 & 1.29 & $3-225$ & 2.1 & Natural Waters, Human hairs & 12 \\
\hline 4 & Cysteamine & SAM & 5 & 0.005 & $0.03-317$ & 6.6 & Blood serum & 26 \\
\hline 5 & Natural zeolites & $\mathrm{CPE}$ & 15 & 0.96 & $3.2-322$ & 2.2 & Tomato, Bakosel capsule & 27 \\
\hline 6 & $\begin{array}{l}\text { 2-aminothiazole organofunction- } \\
\text { alized silica }\end{array}$ & CPE & 20 & 1.9 & $4.8-160$ & 2.9 & Ethanol fuel samples & 28 \\
\hline 7 & Calix[4]arene & $\mathrm{CPE}$ & 10 & 1.1 & - & - & Tap waters & 29 \\
\hline 8 & Tripeptide Gly-Gly-His & SAM & 10 & 0.02 & Up to 0.13 & 12.5 & Natural waters & 30 \\
\hline 9 & Nitroso-R & OPPy & 8 & 0.7 & $1.2-243$ & 1.8 & Natural water, Human hair & This work \\
\hline
\end{tabular}

${ }^{\mathrm{a}} \mathrm{t}_{\mathrm{a}}=$ accumulation time, $\mathrm{LOD}=$ limit of detection, $\mathrm{LR}=$ linear range, $\mathrm{SAM}=$ self assembled monolayers, $\mathrm{CPE}=$ carbon paste electrodes.

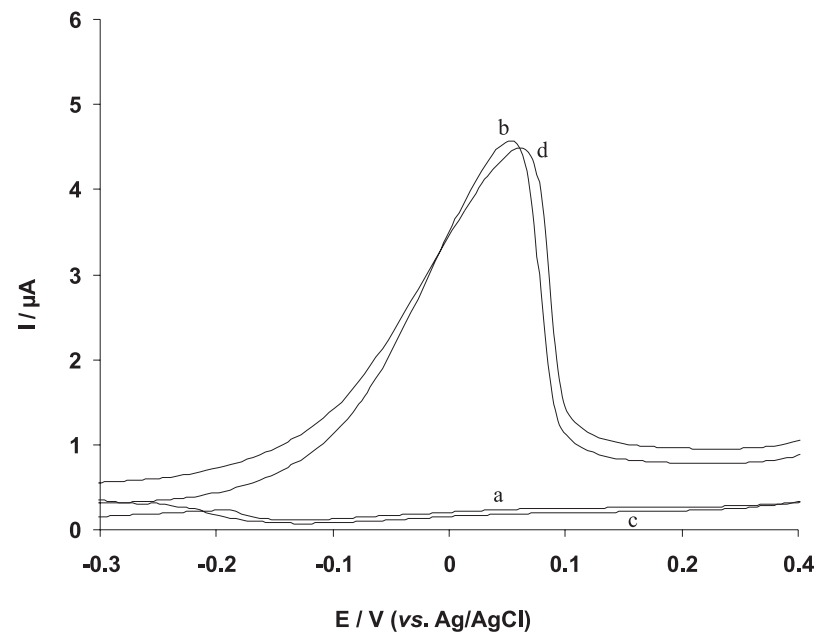

Figure 6. Differential pulse voltammograms of (a) new OPPy/Nitroso-R without accumulation of $\mathrm{Cu}(\mathrm{II})$, (b) new OPPy/Nitroso-R after $8 \mathrm{~min}$ accumulation in $200 \mathrm{ng} \mathrm{mL}^{-1} \mathrm{Cu}$ (II), (c) used OPPy/Nitroso-R after $2 \mathrm{~min}$ immersing in $0.2 \mathrm{~mol} \mathrm{~L}^{-1}$ EDTA, (d) regenerated OPPy/Nitroso-R after $8 \mathrm{~min}$ accumulation in $200 \mathrm{ng} \mathrm{mL}^{-1} \mathrm{Cu}$ (II). All other conditions were the same as in Figure 5.

\section{Conclusions}

We have demonstrated that OPPy film doped with Nitroso-R can be used for the stripping voltammetry of copper(II). Overoxidation of PPy film improves the ability of doped Nitroso-R to extract copper ions into the OPPy film. The analyte ions may be preconcentrated by a chemical interaction with the electrode at the open-circuit potential. This method showed a high selectivity, because of the complexation and the exchange of the medium. The calibration graph of copper(II) was shown to ideally be a

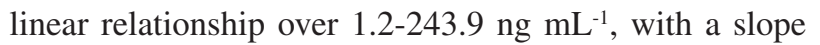
factor of $0.018 \mu \mathrm{A}\left(\mathrm{ng} \mathrm{mL}^{-1}\right)^{-1}$ and a correlation factor of 0.999. We also compared the obtained results in this project with earlier studies reported about stripping voltammetric determination of copper(II) with chemically modified (non$\mathrm{Hg}$ ) electrodes. As can be seen from Table 2, The OPPy/ Nitroso-R modified electrode prepared in this study could be used for the determination of copper(II) in human hair and natural water samples with good results. This present work had a good detection limit $\left(0.7 \mathrm{ng} \mathrm{mL}^{-1}\right)$. It is better than some other reports. , $12,25,27-29,31$ Reproducibility of this work was also very good. Accumulation time was lower compared to some last reports. ${ }^{12,25,27-31}$ Time spent for the preparation of the electrode was very lower than some other techniques. ${ }^{12,26,30}$ This work also shows wider linear range compared to some other reports. ${ }^{6,12,27-28}$

\section{Acknowledgments}

The authors acknowledge with thanks the financial support of Payame Noor University of Kerman (P.N.U.K.) under a research project (No. 0413/4190) in its Chemistry Department.

\section{References}

1. Mahajan, R. K.; Walia, T. P. S.; Lobana, T. S.; Talanta 2005, 67, 755 .

2. Monticelli, D.; Ciceri, E.; Dossi, C.; Anal. Chim. Acta 2007, 594, 192.

3. Gill, E. P.; Garcia, R. M.; Misiego, A. S.; Anal. Chim. Acta 1995, 69, 315 .

4. Gholivand, M. B.; Nassab, H. R.; Fazeli, H.; Talanta 2005, 65, 62 .

5. Trojanowicz, M.; Microchim. Acta 2003, 143, 75.

6. Arrigan, D. W. M.; Lowens, M. J.; Electroanalysis 1999, 111, 647. 
7. Bobacka, J.; Ivaska, A.; Lewenstam, A.; Electroanalysis 2003, $15,366$.

8. Wanekaya, A.; Sadik, O. A.; J. Electroanal. Chem. 2002, 537, 135 .

9. Arrigan, D. W. M.; Gray, D. S.; Anal. Chim. Acta 1999, 402, 157.

10. Shiigi, H.; Yakabe, H.; Kishimoto, M.; Kijima, D.; Zhang, Y.; Sree, U.; Deore, B. A.; Nagaoka, T.; Microchim. Acta 2003, 143, 155 .

11. Shiigi, H.; Kijima, D.; Ikenaga, Y.; Hori, H.; Fukazawa, S.; Nagaoka, T.; J. Electrochem. Soc. 2005, 152, 129.

12. Mohadesi, A.; Taher, M. A.; Talanta 2007, 72, 95.

13. Gao, Z.; Zi, M.; Chen, B.; J.; Electroanal. Chem. 1994, 373, 141.

14. Chen, Z.; Okamura, K.; Hanaki, M.; Nagaoka, T.; Anal. Sci. 2002, 18, 417.

15. Taher, M. A.; Mobarakeh, S.Z.M.; Mohadesi, A.; Turk. J. Chem. 2005, 29, 1.

16. Shiu, K. K.; Pang, S.K.; Cheung, H. K.; J. Electroanal. Chem. 1994, 367, 367.

17. Shiu, K. K.; Chan, O.Y.; Pang, S.; Anal. Chem. 1995, 67, 2828.

18. Taher, M. A.; Anal. Chim. Acta 2000, 408, 153.

19. Taher, M. A.; Talanta 1999, 50, 559.
20. Ramakrishna, V. V. S.; Singh, V.; Garg, A. N.; Sci. Total Environ. 1996, 192, 259

21. Bertazzo, A.; Costa, C.; Biasiolo, M.; Allegri, G.; Cirrincione, G.; Presti, G.; Biol. Trace Elem. Res. 1996, 52, 37.

22. Rao, K. S.; Balaji, T.; Prasada Rao, T.; Babu, Y.; Naidu, G. R. K.; Spectrochim. Acta Part B 2002, 57, 1333.

23. Gad, S. C.; Encyclopedia of Toxicology, Academic Press: San Diego, CA, 2005, pp. 665-667.

24. Brajter, K.; Zlotorzysk, E. D.; Talanta 1986, 33, 149.

25. Nateghi, M. R.; Bagheri, A.; Massoumi, A.; Kazemeini, M. H.; Synth. Met. 1998, 96, 209.

26. Shervedani, R. K.; Mozaffari, S.A.; Anal. Chem. 2006, 78, 4957.

27. Kilinc Alpat, S.; Yuksel, U.; Akcay, H.; Electrochem. Commun. 2005, 7, 130 .

28. Takeuchi, R. M.; Santos, A. L.; Padilha, P. M.; Stradiotto, N. R.; Talanta 2006, 71, 771.

29. Canpolat, E. C.; Sar, E.; Coskun, N.Y.; Cankurtaran, H.; Electroanalysis 2007, 19, 1109.

30. Liu, G.; Nguyen, Q. T.; Chow, E.; Bocking, T.; Hibbert, D. B.; Gooding, J. J.; Electroanalysis 2006, 18, 1141.

31. Mohadesi, A.; Taher, M. A.; Anal. Sci. 2007, 23, 969

Received: September 2, 2007

Web Release Date: May 9, 2008 